\title{
The Proper Scope of Pendent Appellate Jurisdiction in the Collateral Order Context
}

\author{
Riyaz A. Kanji
}

Appellate review of federal district court orders typically requires that the lower court first enter a final judgment in the proceeding to which those rulings pertain. The collateral order doctrine, however, allows for the immediate appeal of a small class of interlocutory determinations. ${ }^{1}$ Several circuits have held that this doctrine confers jurisdiction only over those rulings that satisfy its criteria for expedited review. ${ }^{2}$ Other circuits, by contrast, have declared that once faced with an appeal from a collateral determination below, they may freely consider additional orders rendered by the trial judge, including those potentially dispositive of the underlying litigation. ${ }^{3}$ The latter circuits generally refer to this expansion in their interlocutory review as the exercise of pendent appellate jurisdiction.

This Note contends that the rationale informing the collateral order doctrine supports only a narrow extension of appellate jurisdiction to pendent issues. Part I discusses the final judgment rule and the development of statutory and judicial responses-including collateral order review-to the hardships and inefficiencies the rule can produce. Part II delineates the different approaches adopted by the circuits to the consideration of rulings pendent to an appropriately appealed collateral determination. Part III argues that while a court's expansion of its interlocutory jurisdiction to address issues whose resolution appears logically antecedent to that of a collateral order allows the court properly to fulfill its function of review, any broader exercise of pendent appellate jurisdiction threatens values central to the effective functioning of our judicial system.

1. The doctrine deems immediately reviewable those rulings unrelated to the merits of an action and implicating rights that cannot be vindicated after the entry of judgment. Determinations meeting its requirements include those holding a government official's absolute or qualified immunity from suit, or a criminal defendant's right not to be tried twice for the same offense as guaranteed by the double jeopardy clause of the Constitution, unavailable in a given case. The doctrine is explained in detail, infra notes 20-43 and accompanying text.

2. The First, Third, Fourth, and Ninth Circuits have adopted this approach, and the D.C. Circuit appears to favor it. See infra notes 52-57 and accompanying text.

3. The Second, Fifth, Sixth, Eighth, and Eleventh Circuits adhere to this position. See infra notes 58-64 and accompanying text. 


\section{Finality as a PREREQuisite of ApPellate ReVIEW}

\section{A. The Final Judgment Rule}

Congress has long structured the federal judicial system to allow for appeals in almost all cases only from the final judgment of a lower court. ${ }^{4}$ The Supreme Court has construed this requirement strictly, repeatedly identifying a district court decision that "ends the litigation on the merits and leaves nothing for the court to do but execute the judgment"s as a necessary predicate to appellate review. The final judgment rule guards, the Court has asserted, against the repeated interruption of district court proceedings, making possible the orderly and effective conduct of a trial and the full development of a record for subsequent review. ${ }^{6}$ It prevents the burdening of the appeals courts with the immediate consideration of determinations which might later be rendered moot, either because the party who lost the ruling prevails on the merits or because the issue fails to affect the final judgment in a manner warranting reversal. ${ }^{7}$ And it reduces the ability of parties to "clog the courts through a succession of costly and time-consuming appeals" ${ }^{\prime \prime}$ which could drain their opponents' desire and capacity to pursue meritorious claims.

The final judgment rule also serves to maintain the appropriate relationship between the district and appellate courts. It preserves the respect due trial judges as the initial adjudicators of the nurnerous legal and factual issues that arise during a case by ensuring that their every determination is not subject to the immediate review of an appellate tribunal one step removed from the litigation. The constant specter of such review would reduce the district judge to a token figure. If her rulings could be challenged instantly and as often as the parties desired, they would serve simply as provisional orders having little independent impact on the ongoing conduct of a case. ${ }^{9}$ The consolidation of all contested rulings into a single appeal provides the circuit courts with an opportunity, furthermore, to consider a trial judge's actions in light of the entire

4. DiBella v. United States, 369 U.S. 121, 124 (1962). Congress, acting pursuant to its Article III power to create tribunals inferior to the Supreme Court, incorporated the finality requirement into the first Judiciary Act. See 1 Stat. 73, 83-85 (1789) (providing for appeals only from "final judgments or decrees"). The requirement remains codified at section 1291 of the current Judicial Code, which vests the courts of appeals with "jurisdiction of appeals from all final decisions of the district courts of the United States . . . except where a direct review may be had in the Supreme Court." 28 U.S.C. $\S 1291$ (1988).

5. Catlin v. United States, 324 U.S. 229, 233 (1945) (citation omitted); see also Lauro Lines S.R.L. v. Chasser, 109 S. Ct. 1976, 1978 (1989) (quoting Catlin); Van Cauwenberghe v. Biard, 486 U.S. 517, 52122 (1988) (quoting Catlin); Abney v. United States, 431 U.S. 651, 656 (1977) (noting consistent judicial implementation of congressional policy against piecemeal review).

6. See Richardson-Merrell, Inc. v. Koller, 472 U.S. 424, 430 (1985); Firestone Tire \& Rubber Co. v. Risjord, 449 U.S. 368, 374 (1981); Cobbledick v. United States, 309 U.S. 323, 325-26 (1940).

7. Stringfellow v. Concerned Neighbors in Action, 480 U.S. 370, 380 (1987).

8. Flanagan v. United States, 465 U.S. 259,264 (1984).

9. Firestone Tire \& Rubber Co., 449 U.S. at 374 ("Permitting piecemeal appeals would undermine the independence of the district judge, as well as the special role that individual plays in our judicial system."). 
proceedings below, thereby enhancing the likelihood of sound appellate review of the various issues involved in a litigation. ${ }^{10}$

The final judgment rule is not without serious shortcomings, however. In those situations in which a trial occurs shortly after the institution of proceedings and the trial itself is brief and uncomplicated, there appear to be few negative consequences in allowing a case to advance to its conclusion without the opportunity for interlocutory appeal. But liberal joinder and discovery provisions, the rise of the class action suit, the proliferation of pretrial motions, and a host of other factors have rendered contemporary litigation increasingly lengthy and complex. This development has led to a recognition of the costs attendant upon a rigid adherence to the finality requirement.

Commentators have focused on two failings of the final judgment rule in particular. First, mistaken trial court rulings "may often have serious and continuous effects which cannot be remedied on appeal from the final judgment long in the future."11 The grant or denial of a preliminary injunction, a discovery ruling that forces the release of confidential information, or a determination that a suit may or may not be maintained as a class action are all examples of district court orders which can modify a party's rights swiftly and irremediably. The promptness with which any corrective action is taken in these situations can prove crucial to a reviewing court's success in assuring justice to the litigants. ${ }^{12}$ Even where the delay of appellate review does not threaten parties with the effective loss of significant rights, it can result in wasted expenditures of effort by both the litigants and the courts. An error in the district court may so taint subsequent events as to require reversal and a new trial. Alternatively, the court may erroneously deny a motion that would obviate the need for a trial altogether. Failure to review an order issued early in a case until after final judgment can thus lead to the exertion of "substantial physical, financial and emotional effort in the preparation and conduct of a trial which may later prove to [be] worthless."13

\section{B. Statutory Exceptions}

Recognition of the shortcomings inherent in a rigid application of the final judgment rule has led to the promulgation of exceptions by both Congress and the courts. The most frequently invoked statutory qualification is section 1292(a) of the Judicial Code, which provides the circuit courts with jurisdiction over appeals from, inter alia, "[i]nterlocutory orders of the district

10. See DiBella v. United States, 369 U.S. 121, 129 (1962).

11. R. STERN, APPELLATE PRACTICE IN THE UNTED STATES 79 (2d ed. 1989).

12. Carrington, Toward a Federal Civil Interlocutory Appeals Act, LAW \& CONTEMP. PROBS., Summer 1984 , at 165.

13. Redish, The Pragmatic Approach to Appealability in the Federal Courts, 75 COLUM. L. REV. 89, 98 (1975). 
courts ... granting, continuing, modifying, refusing or dissolving injunctions." ${ }^{14}$ This provision reflects congressional awareness that trial court rulings regarding injunctive relief can be of "serious, perhaps irreparable, consequence" $" 15$ to a litigant and therefore merit immediate review.

Section 1292(b) provides that where a district judge certifies that an order "involves a controlling question of law as to which there is substantial ground for difference of opinion," and further finds "that an immediate appeal from the order may materially advance the ultimate termination of the litigation,"16 an appellate court may consider the ruling on an interlocutory basis. A third exception to the final judgment rule is found in rule 54(b) of the Federal Rules of Civil Procedure, which allows for immediate appeal upon certification by a district judge of orders conclusive with respect to specific parties or claims in a litigation. Its importance heightened by the liberal joinder provisions governing in the federal courts, ${ }^{17}$ the rule serves to protect a litigant whose rights are adjudicated early in a multifaceted case but who, absent the exception, would have to wait for final judgment in the entire action before seeking an appeal.

\section{The Collateral Order Doctrine}

The provisions discussed above fall far short of covering the variety of situations in which a rigid adherence to the final judgment rule might produce serious inefficiency or injustice. Section 1292(a) applies only to injunctive relief, while section 1292(b) and rule 54(b) are limited to civil actions involving complex issues or parties and contain restrictive certification procedures. ${ }^{18} \mathrm{The}$

14. 28 U.S.C. \& 1292(a) (1988).

15. Gardner v. Westinghouse Broadcasting Co., 437 U.S. 478, 480 (1978) (quoting Baltimore Contractors, Inc. v. Bodinger, 348 U.S. 176, 181 (1955)).

16. 28 U.S.C. \& 1292(b) (1988).

17. See FED. R. CIV. P. 19, 20.

18. Requiring trial court certification prior to section 1292 (b) review has provoked increasing criticism. Congress structured section 1292 (b) so as to protect the circuit courts from a flood of ill-founded appeals. Note, Interlocutory Appeals in the Federal Courts Under 28 U.S.C. \$1292(b), 88 HARV. L. REV. 607, 624 (1975). By giving the trial judge complete discretion as to the immediate reviewability of her own determinations, however, Congress vested absolute authority in the individual least likely to perceive the need or desire for such review. As a result, the opportunity for appellate correction of erroneous orders has been minimal, leading Professors James and Hazard to advocate "a procedure in which trial judges can indicate whether they believe interlocutory appeal would be appropriate with regard to particular orders, but in which their adverse views in this respect would not foreclose the appellate court from granting review." F. JAMES \& G. HAZARD, CVIL PROCEDURE \$12.12, at 673 (3d ed. 1985).

The inadequacies which many commentators perceive in the current federal appellate scheme generally have led to numerous calls for a legislative modification of the finality requirement. See, e.g., STERN, supra note 11, at 87; Redish, supra note 13; Note, Toward a More Rational Final Judgment Rule: A Proposal to Amend 28 U.S.C. $\S 1292,67$ GEO. L.J. 1025 (1979). Several state jurisdictions have, indeed, moved significantly away from the final judgment rule. New York, for example, permits appeal as of right from any order which "involves some part of the merits" or "affecis a substantial right." N.Y. CIV. PRAC. L. \& R. \$ 5701(a) (McKinney 1978). In California, the courts have increasingly used the extraordinary writs to review a broad spectrum of rulings prior to final judgment. Christian, Interlocutory Review in California-Practical Justice Unguided by Standards, LAW AND CONTEMP. PROBS., Summer 1984, at 111. See also 
courts have responded by formulating exceptions of their own to the final judgment rule, the most important of which is the collateral order doctrine. ${ }^{19}$

\section{Origins}

The Court established the collateral order doctrine in Cohen v. Beneficial Industrial Loan Corp..$^{20}$ by declaring immediately appealable those rulings that "finally determine claims of right separable from, and collateral to, rights asserted in the action, too important to be denied review and too independent of the cause itself to require that appellate consideration be deferred until the whole case is adjudicated."21 Cohen was a shareholder's derivative suit in which the question arose, prior to trial, whether a New Jersey statute applied in federal court. The statute rendered an unsuccessful plaintiff liable for the defendant's litigation costs and required the plaintiff to post security for those costs in anticipation of the proceedings. ${ }^{22}$ The district court declined to demand such security from the shareholder. Immediate review was sought in the Court of Appeals for the Third Circuit, which reversed the ruling below. The Supreme Court subsequently affirmed the existence of appellate jurisdiction over the pretrial order, identifying three factors central to its determination. First, the district court's ruling denying application of the state statute was in no way "tentative, informal or incomplete." 23 The court had conclusively rejected the corporation's request that security be posted and had ordered the trial to commence. Second, this decision was wholly unrelated to the merits of the action and would not, as a result, be affected by further proceedings in the case. ${ }^{24}$ Third, the lower court order was too important to be denied immediate review, for the asserted right of the corporation to have its litigation costs secured prior to the onset of trial would be "lost, probably irreparably," by the time of final judgment. ${ }^{25}$

STERN, supra note 11 , at $86-88,97-98$ (describing review of interlocutory orders in Georgia, Maine, Massachusetts, Arizona, and others).

19. The Supreme Court sanctioned the first of the judicial departures from the finality requirement well over a century ago. Forgay v. Conrad, 47 U.S. (6 How.) 201 (1848), involved a decree setting aside an assignment of property and directing its immediate delivery to the plaintiff, a trustee in bankruptcy. The decree did not represent a final judgment, for the district court had also ordered an accounting of rents and profits which had yet to be completed. It threatened the defendant assignees with irreparable injury, however, as the trustee planned to dispose of the property and to distribute the proceeds quickly for the benefit of creditors. Recognizing this threat, the Court created an exception to the final judgment requirement which, although never expanded beyond cases involving the imminent disposition of property, survives to this day.

20. 337 U.S. 541 (1949).

21. Id. at 546.

22. The subject matter jurisdiction of the federal court rested on the diverse citizenship of the parties. Id. at 543 .

23. Id. at 546 .

24. Id. ("[T]his order of the District Court did not make any step toward final disposition of the merits of the case and will not be merged in final judgment.").

25. Id. 


\section{Evolution: Scrutinizing the Need for Immediate Review}

The Cohen Court asserted that it was not forging an exception to section 1291, but rather was supplying a reasonable construction of the statutory requirement that there exist a final decision prior to appeal. ${ }^{26}$ Despite this claim, it is difficult to interpret the Court's decision as other than one which sanctioned immediate review of an interlocutory order. ${ }^{27}$ For, as Professor Redish has noted, "[i]t is clear that the litigation would have continued . . . had the court of appeals refused to review the trial court's denial of the defendant corporation's motion." 28 An examination of the collateral order doctrine's subsequent development reveals, indeed, that it is best explained as a tailored reaction to the starkest failings of the finality requirement.

In its early collateral order decisions, the Court did not apply with any degree of rigor the factors laid out in Cohen for determining appealability. Instead, the Court interpreted Cohen expansively, focusing on its general proposition that certain rulings can be reviewed on an interlocutory basis. In Stack v. Boyle, ${ }^{29}$ for example, the Court simply cited to Cohen as authority for declaring an Eighth Amendment excessive bail claim immediately appealable. In a string of more recent cases, however, the Court has limited the reach of Cohen by placing a greater emphasis on the specific criteria-conclusiveness, separability from the merits, and the importance of immediate review-articulated in that decision as a basis for appealability. It has paid particularly close attention to Cohen's third requirement, scrutinizing orders to ascertain the consequences of delaying their review until final judgment.

Abney v. United States ${ }^{30}$ represents the first of the Court's efforts in this direction. In holding an order denying a motion to dismiss an indictment on double jeopardy grounds immediately appealable, the Court first observed that the district judge had definitively rejected the defendant's Fifth Amendment defense. ${ }^{31}$ It then determined that by its very nature a claim of double jeopardy is collateral to the main thrust of a criminal trial. ${ }^{32}$ Devoting the bulk of its attention to the question of whether review of the defendant's claim could await the final decision of the lower court, the Court concluded that the rights accorded by the double jeopardy clause could not be vindicated at that stage, because the very guarantee of the clause is against being tried twice for the

26. Id. Justice Jackson, the author of the Cohen opinion, reiterated the claim several years later. See Stack v. Boyle, 342 U.S. 1, 12 (1951) (Jackson, J., concurring).

27. The Court itself has subsequently acknowledged this fact. See Coopers \& Lybrand v. Livesay, 437 U.S. 463, 467-68 (1978) ("[A]n [interlocutory] order is appealable . . . only if it comes within an appropriate exception to the final-judgment rule . . . . In this case respondents rely on the 'collateral order' exception articulated by this Court in Cohen .....").

28. Redish, supra note 13 , at 94 .

29. 342 U.S. 1 (1951).

30. 431 U.S. 651 (1977).

31. Id. at 659 .

32. $I d$. at 659-60. 
same offense. To force an individual to undergo the strain, humiliation, and expense of trial before allowing her to take an appeal would be to sap her asserted constitutional right of all substance..$^{33}$

The Court has recognized a right analogous to that identified in Abney in one other category of cases frequently mentioned by litigants. In Helstoski $v$. Meanor, ${ }^{34}$ the Court held that the privilege granted members of Congress by the speech and debate clause against having to answer for their legislative statements in any place other than Congress implicated a right not to be tried on the basis of those statements similar to that guaranteed by the double jeopardy clause. ${ }^{35}$ The Court subsequently has classified immunities enjoyed by other government officials as protections not merely from liability but from suit and as thus requiring vindication prior to the commencement of trial. ${ }^{36}$

In numerous other cases, however, the Court has rejected litigants' assertions as to the need for immediate review of a lower court ruling. On several occasions, it has done so with respect to claims of immunity from the judicial process that, while similar to those advanced in the double jeopardy and government official cases, it has viewed as less important. In Lauro Lines S.R.L. v. Chasser, ${ }^{37}$ for example, the Court refused to extend the collateral order doctrine to claims implicating a right not to be sued or tried in a particular tribunal as distinguished from a right not to be tried at all, although it recognized that the former could not be "perfectly secured by appeal after final judgment." ${ }^{38}$ Similarly, in United States v. Hollywood Motor Car Co. ${ }^{39}$ the Court concluded that the protection afforded by the due process clause against prosecutorial vindictiveness "is simply not one that must be upheld prior to trial," ${ }^{40}$ despite precedent holding that victims of such vindictiveness may " "not be haled into court at all upon [a resulting] charge." "41

The Court has also denied immediate appellate consideration of claims as to which any prospect of post-trial vindication exists, even if those prospects appear "academic at best." ${ }^{\text {"42 }}$ In Stringfellow v. Concerned Neighbors in Ac-

33. "'The prohibition is not against being twice punished, but against being twice put in jeopardy ...." Id. at 661 (quoting Price v. Georgia, 398 U.S. 323, 326 (1970)).

34. 442 U.S. 500 (1979).

35. Id. at 506 .

36. See Mitchell v. Forsyth, 472 U.S. 511 (1985) (qualified immunity of cabinet official); Nixon v. Fitzgerald, 457 U.S. 731 (1982) (absolute immunity of president).

37. 109 S. Ct. 1976 (1989).

38. Id. at 1979. In his concurring opinion, Justice Scalia noted that "[t]he reason we say that the [shipowner's] right not to be sued elsewhere than in [Italy] is 'adequately vindicable' by merely reversing any judgment obtained in violation of it is, quite simply, that the law does not deem the right important enough to be vindicated by, as it were, an injunction against its violation obtained through interlocutory appeal. The importance of the right asserted has always been a significant part of our collateral order doctrine." Id. at 1980 (Scalia, J., concurring) (first emphasis in original; second emphasis supplied).

39. 458 U.S. 263 (1982) (per curiam).

40. Id. at 270 .

41. Id. at 273 (Blackmun, J., dissenting) (quoting Blackledge v. Perry, 417 U.S. 21, 30 (1974)).

42. Stringfellow v. Concerned Neighbors in Action, 480 U.S. 370, 376 (1987). 
tion, $^{43}$ for example, the Court held that a district court order granting the respondent CNA permissive intervention subject to various conditions, but denying it intervention as of right, fell outside the Cohen exception to the final judgment rule. By virtue of its status as a permissive intervenor, the Court noted, CNA would be able to raise its objections to the district court's ruling on appeal from final judgment. The Court did not dispute CNA's contention that an appellate tribunal would be extremely reluctant to vacate a district court judgment in a case involving numerous parties and years of litigation because of an erroneous intervention order. But it stated that where the legal contours of CNA's asserted right were such that they would not be completely destroyed absent interlocutory review, it would not grant an exception to the final judgment rule.

The Court has thus limited Cohen's reach to a carefully considered set of circumstances. Only in cases where section 1291's jurisdictional requirement would, if mechanically applied, eliminate the role of the appellate courts altogether with respect to claims deemed essential to litigants, has the Court countenanced a departure from its rigidities. Where the foreclosure of appellate review has appeared any less stark, however, the Court has maintained a stringent adherence to the finality rule.

\section{THE Divergent ApProaches to the Proper SCOPE Of APPellate REVIEW IN THE COLLATERAL ORDER CONTEXT}

\section{A. The Supreme Court}

In Abney v. United States ${ }^{44}$ and its successors, the Supreme Court clearly delineated the permissible bounds of collateral order jurisdiction. The Court has not fared as well, however, in attempting to establish the extent to which appellate tribunals may, in reviewing collateral orders, exercise pendent appellate jurisdiction over other rulings in the same case that do not, by themselves, satisfy the Cohen requirements for expedited review.

In Eisen v. Carlisle \& Jacquelin ${ }^{45}$ the Court appeared to sanction the extension of collateral order jurisdiction to pendent rulings. After determining that an order allocating ninety percent of the costs of plaintiff class notification to the defendants in a securities action fell within the confines of the Cohen doctrine, ${ }^{46}$ the Court asserted that appellate jurisdiction also existed to address the trial judge's conclusion that individual notice only had to be provided to a limited number of class members, with notice by publication to the remainder. The two rulings, the Court reasoned, were related aspects of the district court's

43. $I d$.

44. 431 U.S. 651 (1977).

45. 417 U.S. 156 (1974).

46. Id. at 172 . 
construction of the Federal Rules of Civil Procedure in a manner that allowed the suit to proceed as a class action despite the representative plaintiff's contention that he could not bear the costs of notification to all members of the class. It followed that the appellate tribunal should consider the rulings together in order to render a fully informed determination as to the propriety of the class suit, even though the notice-by-publication ruling did not, standing alone, satisfy the requirements of the collateral order doctrine. ${ }^{47}$

Three years later, however, the Court took a markedly different approach to the question of pendent review. After deciding, in Abney, that an appeal predicated on double jeopardy grounds could be raised immediately, ${ }^{48}$ the Court declared that the petitioner's challenge to the sufficiency of his indictment could not be heard at the same time. Appellate jurisdiction extended only to those determinations meeting the Cohen criteria. Review of all other claims would have to await the entry of judgment:

Our conclusion that a defendant may seek immediate appellate review of a district court's rejection of his double jeopardy claim is based on the special considerations permeating claims of that nature which justify a departure from the normal rule of finality. Quite obviously, such considerations do not extend beyond the claim of former jeopardy .... [Other] claims are appealable if, and only if, they too fall within Cohen's collateral-order exception to the final-judgment rule. $^{49}$

Despite the strong pronouncement contained in Abney, the propriety of pendent appellate jurisdiction remains an open question. Perhaps Abney's failure to address the conflicting views expressed in Eisen, or to consider the main justifications set forth by those circuits that exercise an expanded scope of collateral order review, ${ }^{50}$ is responsible for the persisting debate. But for whatever reason, the appellate courts continue to evince widely differing attitudes, as Justice White noted some eight years after Abney, ${ }^{51}$ toward the appropriate bounds of their authority when faced with an interlocutory appeal under Cohen.

47. Id.

48. See supra notes $30-33$ and accompanying text.

49. Abney, 431 U.S. at 663 . In United States v. MacDonald, 435 U.S. 850, 857 n.6 (1978), the Court reiterated this view, rejecting the Fourth Circuit's argument that it could hear a defendant's speedy trial claim as pendent to his double jeopardy appeal.

50. These justifications are set forth in Section III.A., infra.

51. San Filippo v. United States Trust Co., 470 U.S. 1035, 1036-37 (1985) (White, J., dissenting from denial of certiorari.). 


\section{B. The Circuit Courts}

Several circuits have followed the command of the Abney Court that they enjoy jurisdiction in the collateral order context only to hear those claims that independently fulfill the Cohen requirements for interlocutory review. In United States v. Cerilli, ${ }^{52}$ the Third Circuit refused to consider, pendent to a defendant's double jeopardy appeal, claims that his indictment was barred by a statute of limitations and had been tarnished by prosecutorial misconduct. The latter contentions, the circuit court noted, could be adequately addressed after final judgment. Under Abney, then, review of these contentions would have to wait. ${ }^{53}$ The First, ${ }^{54}$ Fourth, ${ }^{55}$ Ninth, ${ }^{56}$ and D.C. ${ }^{57}$ Circuits similarly have refused to exercise jurisdiction over claims pendent to the collateral orders properly before them.

A number of other circuits, however, have addressed additional issues when faced with an appeal satisfying the Cohen requirements. In San Filippo v. United States Trust Co. of New York, ${ }^{58}$ the leading Second Circuit case in this regard, the court heard and rejected, pursuant to the collateral order doctrine, the defendants' absolute immunity appeal. It went on to dismiss the case, though, on the ground that the plaintiff had failed to state a claim. In explaining that it enjoyed jurisdiction to consider the sufficiency of the plaintiff's pleadings, the court made reference to neither Eisen nor Abney. It simply stated

52. 558 F.2d 697 (3d Cir.), cert. denied, 434 U.S. 966 (1977).

53. Id. at 699-700; see also Forsyth v. Kleindienst, 599 F.2d 1203, 1209 (3d Cir. 1979) (addressing only assertion of absolute immunity), cert. denied, 453 U.S. 913 (1981); Akerly v. Red Barn System, Inc., 551 F.2d 539, 542-43 (3d Cir. 1977) (rejecting review of order denying motion to dismiss complaint on grounds of attorney misconduct while reviewing order denying disqualification of attorney).

54. See, e.g., Newman v. Massachusetts, 884 F.2d 19, 22 (1st Cir. 1989) (adhering to "well-established" First Circuit practice in limiting interlocutory review to issue of qualified immunity), cert. denied, $110 \mathrm{~S}$. Ct. 1131 (1990); Quintana v. Anselmi, 817 F.2d 891, 892 n.3 (1st Cir. 1987) (refusing to consider appropriateness of injunctive relief along with qualified immunity appeal); Monge-Vasquez v. RohenaBetancourt, 813 F.2d 22, 23 n.1 (1st Cir. 1987) (same).

55. See, e.g., United States v. Blackwell, 900 F.2d 742, 746-47 (4th Cir. 1990) (declining to review, in context of double jeopardy appeal, orders denying motions to dismiss indictment on grounds of improper venue and impermissible forum shopping).

56. See, e.g., Manhattan Beach Police Officers Ass'n v. City of Manhattan Beach, 881 F.2d 816, 817-18 (9th Cir. 1989) (scope of review limited to issue of immunity); Todd v. United States, 849 F.2d 365, 368 (9th Cir. 1988) (same); United States v. Claiborne, 727 F.2d 842, 849 (9th Cir.) (same), cert. denied, 469 U.S. 829 (1984); United States v. Yellow Freight Sys., 637 F.2d 1248, 1251 (9th Cir. 1980) ("Inquiry into the immediate appealability of a particular pretrial order must focus upon each claim asserted. Thus immediate appealability of one of the defendants' claims will not confer pendent appellate jurisdiction over defendants' other claims.") (citing Abney), cert. denied, 454 U.S. 815 (1981).

57. In Gross v. Winter, 876 F.2d 165, 168 (D.C. Cir. 1989), the circuit criticized without flatly repudiating the notion that it could append an otherwise nonappealable order to the collateral ruling properly before it. It held that for the purposes of the instant case it would not review a denial of the defendant's motion to dismiss for failure to state a claim along with her absolute immunity appeal. See also Browning v. Clerk, United States House of Representatives, 789 F.2d 923, 930 n.14 (D.C. Cir.) (rejecting exercise of pendent appellate jurisdiction in dicta), cert. denied, 479 U.S. 996 (1986). But see Dellums v. Powell, 660 F.2d 802, 804 n.6 (D.C. Cir. 1981) (suggesting discretionary power of court to append noncollateral determination to claim of absolute immunity).

58. 737 F.2d 246 (2d Cir. 1984), cert. denied, 470 U.S. 1035 (1985). 
that the doctrine of pendent appellate jurisdiction allowed it to expand the scope of its interlocutory review beyond the appealable order immediately before it:

\begin{abstract}
[The] defendants raised several additional grounds in the district court in support of their motion for 12(b)(6) dismissal . . . . None of these alternative grounds would in its own right merit interlocutory review under Cohen. However, under the doctrine of pendent appellate jurisdiction, once we have taken jurisdiction over one issue in a case, we may, in our discretion, consider otherwise nonappealable issues in the case as well .... We have invoked that discretionary power to consider issues presenting considerably less overlap than exists here. In view of that fact, and the waste of judicial resources were this suit to go forward, we see every reason to invoke that power in this case..$^{59}$
\end{abstract}

On numerous other occasions, the Second Circuit has invoked the pendent appellate jurisdiction doctrine to review non-Cohen rulings on an interlocutory basis. ${ }^{60}$ The Fifth, ${ }^{61}$ Sixth, ${ }^{62}$ Eighth, ${ }^{63}$ and Eleventh ${ }^{64}$ Circuits have similarly appended additional orders to the collateral determinations properly before them.

59. San Filippo, 737 F.2d at 255 (citations omitted).

60. See, e.g., United States v. Gerena, 869 F.2d 82, 84 (2d Cir. 1989) (considering defendants' fair trial arguments along with collateral order claim alleging violation of statutorily guaranteed privacy rights); Bolden v. Alston, 810 F.2d 353, 356 (2d Cir.) (liability determinations of district judge reviewed pendent to qualified immunity appeal), cert. denied, 484 U.S. 896 (1987); United States v. Persico, 774 F.2d 30, 33 n.2 (2d Cir. 1985) (defendant's allegations of violation of Rule 11 of Federal Rules of Criminal Procedure, though reviewable subsequent to final judgment, considered in conjunction with double jeopardy challenge); United States v. Russotti, 717 F.2d 27,32 n.2 (2d Cir. 1983) (claim of prosecutorial vindictiveness, acknowledged by court to fall outside of Cohen exception to final judgment rule under Supreme Court decision in United States v. Hollywood Motor Car Co., 458 U.S. 263 (1982), reviewed pendent to double jeopardy appeal), cert. denied, 465 U.S. 1022 (1984).

61. See, e.g., Metlin v. Palastra, 729 F.2d 353, 355 (5th Cir. 1984) ("We have recently decided to treat denials of claimed absolute immunity as appealable orders. Our jurisdiction can, in the interest of judicial economy, extend as a matter of discretion to review of [other issues]." (citation omitted)); In re Nissan Motor Corp. Antitrust Litigation, 552 F.2d 1088, 1096 (5th Cir. 1977) (assessing content of class notice along with ruling allocating costs and duties of notification).

62. See, e.g., Foster v. Walsh, 864 F.2d 416, 418 (6th Cir. 1988) (considering, pendent to review of court officer's absolute immunity defense, whether section 1983 claim was stated against municipal court); Carlson v. Conklin, 813 F.2d 769, 770-71 (6th Cir. 1987) (accepting jurisdiction over interlocutory order implicating immunity defense, but deciding case on grounds of failure to state claim).

63. See, e.g., Moreno v. Small Business Admin., 877 F.2d 715, 716 (8th Cir. 1989) (addressing, in context of qualified immunity appeal, defendants' claim that plaintiff stated no Bivens cause of action); Craft v. Wipf, 836 F.2d 412, 417-19 (8th Cir. 1987) (considering whether substantial evidence existed to support plaintiffs' equal protection claim after rejecting defendants' qualified immunity defense); Drake v. Scott, 812 F.2d 395, 399-401 (8th Cir.) (determining on qualified immunity appeal whether plaintiff raised genuine issue of material fact regarding First Amendment allegation or stated due process claim), aff' $d$ on rehearing, 823 F.2d 239 (8th Cir.), cert. denied, 484 U.S. 965 (1987).

64. See, e.g., Stewart v. Baldwin County Bd. of Educ., 908 F.2d 1499, 1509 (11th Cir. 1990) (stating that "[p]endent jurisdiction is properly exercised over nonappealable decisions of the district court when the reviewing court already has jurisdiction over one issue in the case" in considering school board's Eleventh Amendment immunity claim pendent to board members' absolute and qualified immunity appeals); Broughton v. Courtney, 861 F.2d 639, 641 n.1 (11th Cir. 1988) (grounding jurisdiction in defendant's absolute immunity appeal but resolving case on basis of federal law preemption of state claims). 


\section{ThE APPRopriate CONTOURS OF PENDENT APPEllate JURISDICTION}

\section{A. The Need For Limits}

The argument set forth by many of the circuits that exercise pendent appellate jurisdiction is an attractive one. Once a trial has been interrupted and their appellate jurisdiction invoked under the collateral order doctrine, they assert, it makes sense for them to consider other issues in the case if doing so might speed up the course of the litigation. Consideration of clearly interlocutory rulings, they point out, can further the goal of judicial economy in one of two ways. Where addressing the pendent determinations enables an appellate court to dispose of the litigation entirely, for example by granting a defendant's motion to dismiss for failure to state a claim, "the waste of judicial resources were th[e] suit to go forward" is thereby avoided..$^{65}$ Where a case is destined to continue on remand, on the other hand, circuit court guidance as to important issues might "not only minimize the possibility of an expensive and timeconsuming retrial ... [but] result in a more expeditious trial [in the first instance]." 66 Several factors suggest the need, however, to cabin the circumstances in which a court can exercise pendent appellate jurisdiction.

\section{Jurisdictional Constraints}

The collateral order doctrine represents an exception to the well-established principle that "the existence of appellate jurisdiction in a specific federal court over a given type of case is dependent upon authority expressly conferred by statute." 67 Congress' Article III power to create the lower federal courts enables it to organize their operations as it sees fit. ${ }^{68}$ Its decision, reflected in section 1291, to delay appellate review of district court orders until after final judgment has accordingly been shown great deference by the Supreme Court. The Court has stressed, for example, that the "factual circumstances that underlie a[n] [interlocutory] claim, however 'extraordinary,' cannot establish its independent appealability." 69 It has similarly emphasized that whether an order appears correctly decided has nothing to do with when it may properly

65. San Filippo v. United States Trust Co. of New York, 737 F.2d 246, 255 (2d Cir. 1984), cert. denied, 470 U.S. 1035 (1985); see also Metlin, 729 F.2d at 355 (resting review of dispositive issue on principle of "judicial economy"); United States v. MacDonald, 531 F.2d 196, 199-200 (4th Cir. 1976) (same), rev'd, 435 U.S. 850 (1978).

66. Green v. Wolf Corp., 406 F.2d 291, 302 (2d Cir. 1968), cert. denied, 395 U.S. 977 (1969).

67. Carroll v. United States, 354 U.S. 394, 399 (1957).

68. Finley v. United States, 109 S. Ct. 2003, 2006 (1989) ("'[T]wo things are necessary to create jurisdiction, whether original or appellate. The Constitution must have given the court the capacity to take it, and an act of Congress must have supplied it . . . . To the extent that such action is not taken, the power lies dormant." ) (quoting The Mayor v. Cooper, 73 U.S. (6 Wall.) 247, 252 (1868) (emphasis added by Finley Court)).

69. United States v. MacDonald, 435 U.S. 850,858 n.6 (1978). 
be reconsidered. "Permitting wholesale appeals on that ground ... [would create] a license for broad disregard of the finality rule imposed by Congress in § 1291." can justify premature review. ${ }^{71}$ Only where a rigid adherence to section 1291 would act not simply to delay appellate review, but would foreclose such review altogether on issues of tremendous significance, has the Court invoked the Cohen rule.

The exercise of pendent appellate jurisdiction constitutes, as detailed above, an extension in the reach of the collateral order doctrine. Determinations are brought within its ambit that would not, by themselves, comport with its requirements for expedited review. Given the Court's recognition of the limited circumstances in which a departure from section 1291 is warranted, it would seem appropriate for appellate tribunals to append additional interlocutory decisions to Cohen rulings only when necessary to afford parties the adequate review of their claims contemplated by the collateral order doctrine.

\section{Respect for the District Courts}

Because most collateral order appeals are raised in the pretrial stage, it would appear unlikely that an appellate court could reach out to address factual determinations as an aspect of its Cohen review even if it desired to do so. Situations have arisen, however, where courts have exercised pendent appellate jurisdiction to consider the interim liability rulings of a trial judge in the course of hearing a Cohen appeal. In Bolden v. Alston, ${ }^{72}$ for example, several prison officials who had allegedly denied an inmate his procedural due process rights appealed an adverse qualified immunity ruling during the middle of their trial. They phrased their challenge in a manner which implicated the correctness of one of the district judge's factual determinations, and the circuit court exercised pendent appellate jurisdiction to consider the merits of this determination before remanding the case for further proceedings.

By acting in such a manner, courts often remove from the hands of a district judge issues on which she has not rendered her final word. They lose the benefits of her unique insight into a litigation, insight stemming from her direct exposure to the salient facts and nuances of a case. ${ }^{73}$ They further deprive themselves of the perspective which the full record in a case can provide. ${ }^{74}$

70. Firestone Tire \& Rubber Co. v. Risjord, 449 U.S. 368, 378 (1981).

71. Coopers \& Lybrand v. Livesay, 437 U.S. 463,470 (1978) ("Respondents . . . argue that the class action serves a vital public interest and, therefore, special rules of appellate review are necessary to ensure that district judges are subject to adequate supervision and control. Such policy arguments . . . are irrelevant to the issue we must decide.").

72. 810 F.2d 353 (2d Cir.), cert. denied, 484 U.S. 896 (1987).

73. See Wright, The Doubtful Omniscience of Appellate Courts, 41 MinN. L. REV. 751, 781-82 (1957); Green, Jury Trial and Mr. Justice Black, 65 YALE L.J. 482, 486 (1956).

74. Parkinson v. April Indus., 520 F.2d 650, 652 (2d Cir. 1975). 
The pendent appellate jurisdiction doctrine should thus be defined to preclude premature circuit court consideration of factual issues, lest the essential role of the trial judge in our judicial system be undermined.

\section{Bootstrapping}

A final argument in favor of circumscribing the scope of pendent appellate jurisdiction focuses on considerations of judicial efficiency which threaten to outweigh the doctrine's promised gains. A significant reason for narrowly defining the orders from which an appeal may be taken is to avoid the repeated disruption of district court proceedings which renders impossible the efficient conduct of a trial. The Supreme Court has repeatedly cited the cost and delay inherent in shuttling a case back and forth between tribunals as supporting its policy against piecemeal review. ${ }^{75}$

The circuits exercising pendent appellate jurisdiction do not often implicate this policy because they utilize the doctrine in a context where an interlocutory appeal has already been allowed. Were appellate courts to display an unbridled willingness to hear claims important to litigants as part of their collateral order review, however, they would provide both an incentive and the means for parties to circumvent the final judgment rule by bootstrapping issues they desire to have considered onto claims they otherwise would not raise. The Abney Court referred to this danger as a principal reason for rejecting collective appellate dispatch of the related issues in a case. A significant number of criminal defendants, the Court argued, might find themselves in the position of being able to "assert[] frivolous double jeopardy claims in order to bring more serious, but otherwise nonappealable questions to the attention of the courts of appeals prior to conviction and sentence." able almost by definition to raise some sort of immunity defense, similarly could do just that in order to short-circuit the trial process and receive earlier appellate consideration of other matters. Clearly, then, the permissible boundaries of pendent appellate jurisdiction must not be drawn so broadly as to allow for the disingenuous initiation of interlocutory appeals.

\section{B. Defining the Parameters}

\section{Deckert}

The Supreme Court's decision in Deckert v. Independence Shares Corp. ${ }^{77}$ serves as an instructive starting point in defining the desired limits on pendent appellate jurisdiction. Deckert did not concern an appeal under the collateral

75. See supra notes 6-8 and accompanying text.

76. Abney v. United States, 431 U.S. 651, 663 (1977).

77. 311 U.S. 282 (1940). 
order doctrine, but instead an appeal from a preliminary injunction which prevented the defendant from disposing of certain funds claimed by the plaintiff. $^{78}$ The Court held that the appellate tribunal could properly review, in conjunction with this order, the denial of the defendant's motions to dismiss the bill for failure to state a cause of action and for lack of subject matter jurisdiction. ${ }^{79}$ At the same time, the Court declared that the trial judge's rulings allowing for the addition of two plaintiffs and referring an issue of insolvency to a master could not be appealed until after final judgment. ${ }^{80}$

Deckert followed a line of older Court cases standing for the proposition that where an appellate tribunal reviews an interlocutory order implicating injunctive relief, it is not limited to scrutiny of this order, but may examine the legal contours of the underlying action to determine " "[i]f insuperable objection to maintaining the bill clearly appears. " "81 If such objection, whether jurisdictional or substantive in nature, exists, the court may dismiss the litigation. Thus, in Mast, Foos \& Co. v. Stover Manufacturing Co. ${ }^{82}$ the Court upheld an appellate tribunal's termination, on review of a preliminary injunction, of an action brought for the infringement of a patent, declaring that "if the bill be obviously devoid of equity upon its face, ... we know of no reason why, to save a protracted litigation, the court may not order the bill to be dismissed."83 Similarly, in Metropolitan Water Co. v. Kaw Valley Drainage District, ${ }^{84}$ the Court approved an appeals court's decision to enter a final decree against the plaintiff for want of jurisdiction in the course of reviewing the grant of a temporary injunction. ${ }^{85}$ In Ex parte National Enameling \& Stamping Co. ${ }^{86}$ on the other hand, the Court declared that a plaintiff's cross-appeal from an order adjudging several of its patents invalid or not infringed could not be heard along with the defendant's appeal from an associated order decreeing other patents infringed and enjoining further violations pending the calculation of damages. Consideration of the cross-appeal, the Court reasoned, would take the

78. Section 129 of the Judicial Cade, the predecessor to 28 U.S.C. $§ 1292$ (a), authorized interlocutory review of the injunction. Deckert, 311 U.S. at 286-87.

79. Id. at 287.

80. Id. at $290-91$.

81. Id. at 287 (quoting Meccano, Ltd. v. John Wanamaker, 253 U.S. 136, 141 (1920)).

82. 177 U.S. 485 (1900).

83. Id. at 495; see also Eagle Glass \& Mfg. Co. v. Rowe, 245 U.S. 275, 280-81 (1917) (noting appellate court's authority to determine, on review of order granting injunction, whether bill stated a claim where plaintiff sought to restrain defendant union from interfering with existing labor relations); City \& County of Denver v. New York Trust Co., 229 U.S. 123 (1913) (dissolving temporary injunctions and directing appellate court to dismiss bills against city in suit involving water plant); Smith v. Vulcan Iron Works, 165 U.S. 518 (1897) (upholding circuit court's termination, on interlocutory appeal, of action alleging patent infringement).

84. 223 U.S. 519 (1912).

85. Id. at 523 . The Court agreed that the plaintiff was not entitled to maintain a federal suit to enjoin a local water district from condemning a parcel of land, where proceedings had been instituted by the water authorities in state court and the requirements of the federal removal statute had not been met.

86. 201 U.S. 156 (1906). 
appellate tribunal far beyond a determination of whether there existed fundamental objection to the original bill. ${ }^{87}$

\section{The Principle of Antecedence}

Appellate courts continue to cite to the Deckert line of cases regularly in examining, pursuant to section 1292(a), the jurisdictional and substantive bases for suits. ${ }^{88}$ A number of circuits faced with injunctive orders have built on the Deckert holding, moreover, in extending the scope of pendent review beyond consideration of whether a case can be maintained.

The principle informing Deckert and its doctrinal predecessors appears to be one of antecedence. A circuit court may properly examine, in determining the appropriateness of injunctive relief, whether an action states a claim, because where no claim is made out the plaintiff cannot enjoy the reasonable likelihood of success on the merits typically required for a preliminary injunction to issue. ${ }^{89}$ Similarly, the court can assess whether jurisdiction over a cause exists, because if jurisdiction is lacking the court possesses no authority to afford equitable relief. A determination regarding the propriety of injunctive relief may turn on the issues of jurisdiction or legal sufficiency, that is, and where it does, those issues can be resolved on the same appeal.

Questions going to the very heart of whether a cause of action can be maintained are not the only matters of law, however, which a court might find antecedent to the consideration of an injunctive order. Thus, in Port Authority Police Benevolent Association v. Port Authority of New York \& New Jersey, ${ }^{90}$ the Second Circuit considered an appeal from rulings denying class certification and a preliminary injunction to the plaintiffs. Ordinarily, the court noted, the disposition of a class action motion is not reviewable prior to final judgment. In this case, however, the district court's denial of an injunction, clearly appealable pursuant to section 1292(a), had been premised on a finding that the plaintiffs were unlikely to succeed on the merits. The district court had based this finding, in turn, solely on the denial of class status. The appeals court therefore held it necessary to consider the propriety of class certification prior to determining whether the plaintiffs should be granted injunctive relief. Similarly, in Tri-State Generation \& Transmission Association v. Shoshone River Power, Inc. ${ }^{91}$ the Tenth Circuit deemed it imperative, in the course of

87. Id. at 162-63.

88. See, e.g., San Filippo v. United Bhd. of Carpenters \& Joiners, 525 F.2d 508, 513 (2d Cir. 1975) ("Where ... there is an appeal otherwise properly before this Court, and the absence of subject matter jurisdiction is suggested, that issue may be reviewed.") (citing Smith v. Vulcan Iron Works, 165 U.S. 518 (1897)).

89. See Doran v. Salem Inn, Inc., 422 U.S. 922, 931 (1975) (detailing traditional standards for preliminary injunction).

90. 698 F.2d 150 (2d Cir. 1983).

91. 874 F.2d 1346 (10th Cir. 1989). 
a section 1292(a) appeal, to consider the trial judge's grant of partial summary judgment against the plaintiff, for this ruling had influenced the judge's subsequent determination that the injunctive relief sought by the plaintiff was overly broad..$^{92}$

Courts deeming pendent review appropriate where logically requisite to determining the propriety of equitable relief have strictly assessed the necessity, however, of considering additional orders in any given case. In Kershner $v$. Mazurkiewicz, ${ }^{93}$ for example, the Third Circuit declined to address a class certification denial where the district judge had refused to issue an injunction for reasons unrelated to that determination. A pendent order, the court emphasized, "is not appealable under section 1292(a)(1) unless the preliminary injunction issue cannot properly be decided without reference to [it]."94 Only where orders "bear upon and are central to the grant or denial of [an] injunction" have such courts reviewed them at the same time..$^{95}$

\section{Application to Collateral Order Review}

The principle of antecedence, suggested by the Deckert line of cases and developed by various circuit courts in considering their scope of review when faced with interlocutory rulings implicating injunctive relief, should be imported into the collateral order context. The purpose of Cohen review in ensuring that rights of serious consequence to litigants are not lost prior to the opportunity for an appeal in many ways mirrors section 1292(a)'s goal of guarding against irreparable injury. It would therefore appear appropriate-indeed, essential-for collateral order courts, like their section 1292(a) counterparts, to consider all factors material to a determination of whether a collateral order was properly decided..$^{96}$

92. Id. at 1351-53; see also Payne v. Travenol Laboratories, Inc., 673 F.2d 798, 808 (5th Cir.) ("Our established power to review the denial of injunctive relief embraces the power to review the orders that underpin this denial."), cert. denied, 459 U.S. 1038 (1982); Jenkins v. Blue Cross Mut. Hosp. Ins., Inc., 522 F.2d 1235, 1238 (7th Cir. 1975) ("[T] he refusal to certify the suit as a class action limited the potential injunctive relief which the plaintiff could obtain, and accordingly can be appealed at this time."), aff $d$ on rehearing, 538 F.2d 164 (7th Cir.), cert. denied, 429 U.S. 986 (1976).

93. 670 F.2d 440 (3d Cir. 1982).

94. Id. at 449; see also Hoxworth v. Blinder, Robinson \& Co., 903 F.2d 186, 209 (3d Cir. 1990) (stating that "pendent appellate jurisdiction over an otherwise unappealable order is available only to the extent necessary to ensure meaningful review of an appealable order" in declining to consider class certification ruling where preliminary injunction had to be vacated regardless of its propriety); Shaffer v. Globe Protection, Inc., 721 F.2d 1121, 1124 (7th Cir. 1983) (concluding that district judge's dismissal of conspiracy claim under 42 U.S.C. $\$ 1985$ was irrelevant to subsequent denial of preliminary injunction); Alexander v. Chicago Park Dist., 709 F.2d 463, 470-71 (7th Cir. 1983) (rejecting consideration of trial judge's refusal to disqualify himself in course of reviewing order denying preliminary injunction).

95. Shaffer, 721 F.2d at 1124.

96. Cf. Kershner v. Mazurkiewicz, 670 F.2d 440, 449 (3d Cir. 1982) ("[A]ny more limited review would deprive the appellant of his or her . . . right to a[n] . . . interlocutory appeal."). 
Acting consistent with this logic, the Fifth Circuit, in United States $v$. Wright, ${ }^{97}$ reviewed a decision denying a motion to dismiss an indictment on prosecutorial misconduct grounds insofar as it bore on the defendant's double jeopardy appeal. The prosecutorial misconduct ruling did not constitute a collateral order and as a result was not immediately appealable. ${ }^{98}$ The court realized, however, that issues implicated by the ruling were central to the defendant's double jeopardy claim, ${ }^{99}$ which rested on the fact that he had already stood trial on the counts alleged in the indictment; the proceeding had resulted in the declaration of a mistrial, granted on the defendant's motion, due to a deadlocked jury. ${ }^{100}$ Normally, the court noted, a mistrial granted upon a defendant's request does not bar reprosecution. An exception to this rule exists, however, where the defendant is forced to move for mistrial due to prosecutorial overreaching, and the defendant had alleged precisely such overreaching below. Hence, it was necessary for the appellate court to review the misconduct issue, though the court stressed that it would do so only "inasmuch as [that issue] relate[d] to the double jeopardy question."101

Similarly, in Drake v. Scott ${ }^{102}$ the Eighth Circuit deemed it appropriate to reach, in the context of a qualified immunity appeal, the district court's refusal to dismiss a due process action against a number of state officials for failure to state a claim. The defendants contended that the plaintiff's allegations that they had fired him without due process did not give rise to a cause of action because the plaintiff enjoyed no property interest in his job. Since the question of whether the officials had violated clearly established law, which represents the core of qualified immunity analysis, "depend[ed] in large part on whether [the] defendants knew or should have known that [the plaintiff] had a clearly established property interest in [his] job at the time they fired him," 103 determination of whether such a property interest existed, and hence of whether a claim was made out, appeared an essential step in resolving the collateral order. ${ }^{104}$ Assessing the applicability of qualified immunity protection to the defendant's actions rested very much, then, on a consideration of whether a violation of law could have transpired at all.

Allowing for pendent appellate jurisdiction in the manner exercised by the Wright or Drake courts does not contravene the demanding requirements the Supreme Court has established in sanctioning departures from the final judgment rule. Assessing pendent rulings to the extent necessary to assure parties

97. 622 F.2d 792 (5th Cir.), cert. denied, 449 U.S. 961 (1980).

98. Id. at 794 .

99. Id. at 794-95.

100. Id. at 793.

101. Id. (1987)

102. 812 F.2d 395 (8th Cir.), aff'd on rehearing, 823 F.2d 239 (8th Cir.), cert. denied, 484 U.S. 965

103. Id. at 399.

104. Id. 
a complete consideration of their collateral order claims appears consistent with the principle informing the Cohen doctrine that litigants should receive adequate appellate review of determinations implicating important rights.

At the same time, by limiting the scope of pendent appellate jurisdiction to those rulings of law crucial to the disposition of a collateral order, the standard of antecedence guards against inappropriate use of the doctrine. It eliminates undue appellate intrusion into the district courts' adjudication of factual issues. It curtails, moreover, the incentive and opportunity for parties to initiate frivolous Cohen appeals in order to receive appellate consideration of other claims, for the latter will be reviewed only where, and to the extent, necessary to resolve the collateral determination.

The application of a standard developed by courts reviewing injunctive rulings to the collateral order setting is not meant, however, to obscure the differences between the two contexts. An appellate court enjoys the authority to address a collateral order not only because a ruling of this sort implicates an important right, but also because it constitutes a conclusive resolution of an issue separate from the merits of an action. ${ }^{105}$ The latter requirement does not pertain to the review of injunctive orders, where an assessment of the plaintiff's likelihood of success on the merits represents an integral aspect of the district court's ruling on the propriety of equitable relief. ${ }^{106}$

That there exists a closer nexus between injunctive determinations and the central features of a litigation than is true with respect to most Cohen decisions indicates that fewer claims are likely to be logically antecedent in the collateral order context. In fact, in many of the cases in which collateral order courts have exercised pendent appellate jurisdiction, they have done so over rulings in no way crucial to the disposition of the interlocutory determination properly before them. In San Filippo v. United States Trust Co. of New York, ${ }^{107}$ for example, the Second Circuit did not need to assess the sufficiency of the plaintiff's claims or the evidence presented in support of them in order to determine that the defendants did not enjoy an absolute immunity from suit regardless of the nature of their transgressions. Indeed, the San Filippo court had already rejected the defendants' absolute immunity claim when it turned its attention to the other issues in the case. ${ }^{108}$ Nor was it necessary for the Eleventh Circuit, in Stewart

105. See supra notes 20-29 and accompanying text. The Supreme Court's extension of the Cohen doctrine to qualified immunity claims indicates a willingness on its part, however, to include rulings the review of which might involve an assessment of the viability of the plaintiff's cause of action. For while the Court stated in Mitchell v. Forsyth, 472 U.S. 511, 528 (1985), that a qualified immunity court "need not ... determine whether the plaintiff's allegations actually state a claim," that language apparently referred, as the Eighth Circuit noted in Drake, "to the factual content of the plaintiff's claims," 812 F.2d at 399, and not to questions regarding the legal sufficiency of the complaint which can be important in deciding whether it points to the violation of clearly established law and thereby obviates a qualified immunity defense.

106. See supra note 89 and accompanying text.

107. 737 F.2d 246 (2d Cir. 1984), cert. denied, 470 U.S. 1035 (1985).

108. Id. at 255 . 
v. Baldwin County Board of Education, ${ }^{109}$ to consider whether the defendant school board constituted an arm of the state and was therefore entitled to Eleventh Amendment immunity in order for it to determine whether the school board's members were alleged to have violated clearly established law such that they could not claim a qualified immunity from suit. Justifying their actions by summary reference to considerations of judicial economy, ${ }^{110}$ or by reference to no considerations at all, ${ }^{111}$ courts exercising pendent appellate jurisdiction in this manner display a troubling lack of concern for the well-established limits on their appellate authority. They engage in ever greater departures from the final judgment rule without devoting adequate attention to the costs or the necessity of doing so.

\section{CONCLUSION}

A debate persists among the federal circuit courts as to the proper scope of their review under the collateral order doctrine. While a number of circuits maintain that they may address a wide range of issues once faced with a Cohen appeal, the jurisdictional nature of the finality requirement, and the role of that requirement in furthering the effective functioning of the judicial system, counsel against far-reaching exercises of pendent appellate jurisdiction. Only where essential to the resolution of properly appealed collateral orders should courts extend their Cohen jurisdiction to rulings that would not otherwise qualify for expedited consideration. The purpose of the collateral order doctrine in ensuring that parties receive a timely review of their important claims does not warrant the forging of additional inroads into the final judgment rule any broader than this. 